\title{
Nanocell-encapsulated miR-16-based microRNA Mimic
}

National Cancer Institute

\section{Source}

National Cancer Institute. Nanocell-encapsulated miR-16-based microRNA Mimic. NCI

Thesaurus. Code C121214.

A nanoparticle-based formulation composed of a microRNA 16 (miR-16) mimic, a doublestranded, 23 base pair, synthetic RNA molecule, encapsulated in nonliving bacterial minicells and coated with anti-epidermal growth factor receptor (EGFR) antibodies, with potential antineoplastic activity. Upon intravenous administration and subsequent transfection, nanocell-encapsulated miR-16-based microRNA mimic targets EGFRexpressing tumor cells and facilitates the restoration of expression of the miR-16 family. This leads to the downregulation of the expression of tumor promoting genes and the inhibition of tumor cell growth. In addition, restoration of miR-16 expression sensitizes the tumor cell to certain chemotherapeutic agents. miR-16, a family of microRNAs, is critical to the regulation of gene expression and appears to have a tumor suppressor function; its expression is downregulated in various cancer cell types. 